\title{
COST DIFFERENCE BETWEEN INA-CBGS TARIFF AND HOSPITAL REAL COST IN THE TREATMENT OF TYPE 2 DIABETES MELLITUS WITHIN THE NATIONAL HEALTH INSURANCE PROGRAM
}

\author{
Amy Amanda Chitra Pahlawani'), Ascobat Gani' ${ }^{1}$, Citra Kusuma Rahayu(2) \\ 1)Masters Program in Health Policy and Administration, \\ Faculty of Public Health, Universitas Indonesia \\ 2)Pharmacist Profession, Faculty of Mathematics and Sciences, \\ Universitas Islam Indonesia
}

\begin{abstract}
Background: The Indonesian Case Base Group (INA-CBGs) financing system within the National Health Insurance (NHI) program requires cost effectiveness analysis. This study aimed to investigate cost difference between INA-CBGs tariff and hospital real cost in the treatment of type 2 diabetes mellitus within the national health insurance program.

Subjects and Method: This was a cross-sectional study conducted at Yogyakarta City Hospital, Yogyakarta, Indonesia. A total sample of 9 type 2 DM patients were selected for this study. The DM patients under study were those using antidiuretic combination therapy within the NHI during 2017 to 2018 period. The data of DM patients were collected from the medical record.

Results: Seven patients (36.84\%) used antidiuretic combination of insulin aspart and insulin detemir. The highest effectiveness therapy was insulin combination therapy, long acting insulin, and a glycosidase, also combination therapy of fast acting insulin group, biguanid, and sulfonylureas, the effectiveness percentage of the two combination therapies were $100 \%$. The average direct medical cost of patients with type 2 DM hospitalized in Yogyakarta City Hospital was Rp 3,539,118. Based on ACER, the most cost-effective therapy in class I was combination therapy for fast acting insulin and biguanid. In class II was combination therapy for fast acting insulin and long acting insulin. In class III was combination therapy for biguanid and sulfonylurea. Difference in real costs with INA-CBG's was Rp 37,715,931. There was no significant difference between the real costs and INA-CBG's $(\mathrm{p}=0.285)$.
\end{abstract}

Conclusion: There is no significant difference between the real cost and INA-CBGs.

Keywords: cost difference, diabetes mellitus, antidiuretic combination, INA-CBGs

\section{Correspondence:}

Amy Amanda Chitra Pahlawani. Masters Program in Health Policy and Administration, Faculty of Public Health, Universitas Indonesia, Depok, West Java. Email: amyamandacp@gmail.com Mobile: +6281280778000 .

\section{BACKGROUND}

Diabetes mellitus (DM) is a complex chronic disease that requires ongoing therapeutic treatment to prevent acute complications and reduce the risk of long-term complications (ADA, 2017).

According to the International Diabetes Federation (IDF), in 2015 the number of DM sufferers in adults was 415 million people and it was predicted that in 2040 to be 642 million people. Indonesia ranks 7 th for the country with the highest DM suf- ferers from 10 other countries and is expected to rank 6th in 2040 (IDF, 2015).

In Indonesia, the prevalence of DM that has been diagnosed by a doctor is $1.5 \%$. Whereas in the city of D.I Yogyakarta, the prevalence of DM that has been diagnosed by doctors is $2.6 \%$ and is the highest prevalence of diabetes (Yogyakarta City Government, 2015).

DM occupies the top ten most diseases in Yogyakarta City Hospital, both in outpatients and inpatients. DM was 
ranked first with a total of 10,746 cases in 2011 and increased to 12,294 in 2012 (Dinkes DIY, 2013).

The higher prevalence of DM incidence and the higher medical cost required is the reason for the difficulty of the community and the government in handling it. Thus, a health insurance is needed in the form of health insurance where participants pay a fixed premium (Sunarto, 2011). National Health Insurance (JKN) is a guarantee with the Indonesian Case Base Group (INA-CBG) financing system and is part of the National Social Security System (SJSN) in Indonesia (Permenkes No 59, 2014). With the existence of health insurance in the form of the SJSN policy, people who were previously unable to pay for health services can get health services so that demand for health services is high (Janis, 2014).

Esti (2014) at RSUD dr. Soebandi Jember stated that Novorapid and Metformin insulin combination therapy is the most cost-effective therapy. These problems are the background of researchers to conduct research on the cost effectiveness of using anti-diabetic combination therapy and the difference in real costs with INA CBG rates for patients with type 2 diabetes mellitus JKN inpatients based on the perspective of Yogyakarta City Hospital.

\footnotetext{
SUBJECTS AND METHOD

\section{Study Design}

This was a cross sectional study design. Retrieval of patient data was collected retrospectively based on medical record data in the medical record installation and financial costs in the Yogyakarta City Hospital during the 2017 and 2018 periods.

The study was conducted at Yogyakarta City Hospital in February-August 2018. The population in this study was inpatient type 2 diabetes mellitus patients and were
}

JKN Yogyakarta City $2017 \quad 2017 \quad 2018$ participants. The sampling method used in this study was the purposive sampling method, namely sampling based on considerations or conditions that have been determined (inclusion criteria).

\section{Inclusion and Exclusion Criteria}

Inclusion criteria include:

a. Patients diagnosed with type 2 diabetes mellitus with anti-diabetic combination therapy who are hospitalized in Yogyakarta City Hospital.

b. Patients participating in the National Health Insurance $(\mathrm{JKN})$ with a diagnosis of type 2 diabetes mellitus who were hospitalized in Yogyakarta City Hospital in 2017 and 2018.

c. Patients with a complete medical record and contain basic information needed in research such as patient identity, diagnosis, blood sugar laboratory results, direct medical costs, and there is an INA CBG's code.

d. Patients who have complete financing data and have claimed BPJS Health.

Exclusion criteria include:

a. Patient who died

b. Patients move up to VIP class.

Data collection techniques used in this study are observation techniques by recording data needed for research. The data used are qualitative data and quantitative data for 2017 and 2018. Qualitative data are obtained from medical record data such as patient identity which includes medical record number, age, gender, diagnosis, 2 hour GDP and GDPP laboratory results, drug name, dosage strength. Quantitative data obtained from administration such as the cost of anti-diabetic drugs, non-anti-diabetic drug costs, accommodation costs, service fees, laboratory costs and other support as well as the cost of medical equipment. 
The data that has been obtained subsequently analyzed, includes:

1. Identify the characteristics of research subjects, including the percentage of gender, age, and accompanying diseases.

a. The percentage of gender is calculated based on the number of male and female patients divided by the total number of patients multiplied by $100 \%$.

b. The percentage of age is calculated based on the number of patients each age interval divided by the total number of patients multiplied by $100 \%$.

c. The percentage of comorbidities is calculated based on the number of patients with comorbidities divided by the total number of patients multiplied by $100 \%$.

2. Overview of Therapeutic Treatment for Type 2 Diabetes Mellitus

Percentage of anti-diabetic drugs used by patients to find out the number of drugs used by patients includes drug classes, drug names, strength of preparations, and compliance with National forums.

3. Percent effectiveness of therapy is calculated based on the number of patients who reach the target GDP $(<126$ $\mathrm{mg} / \mathrm{dl})$ and or GDPP 2 hours $(<180$ $\mathrm{mg} / \mathrm{dl}$ ) divided by the total number of patients receiving certain anti-diabetic drug therapy.

4. Calculate the components of direct medical costs including the costs of anti-diabetic drugs, non-anti-diabetic drug costs, accommodation costs, service costs, laboratory and other support costs, and the cost of medical equipment.

a. Anti-diabetic drug costs are calculated based on the average cost of anti-diabetic drugs divided by total direct medical costs.

b. The cost of non-anti-diabetic drugs is calculated based on the average cost of non-anti-diabetic drugs divided by the total direct medical costs.

c. The accommodation fee is calculated based on the average accommodation costs divided by the total direct medical costs.

d. The service fee is calculated based on the average cost used by patients each time getting medical examinations from medical personnel divided by the total direct medical costs.

e. Laboratory and other support costs are calculated based on the average costs used by patients to carry out laboratory examinations and other supports divided by the total direct medical costs.

f. The cost of medical devices is calculated based on the average cost of medical devices used by patients divided by the total direct medical costs.

5. Calculating Cost Effectiveness Analysis (AEB) including the value of ACER and ICER

a. ACER values were obtained from total patient care costs divided by clinical outcomes.

b. ICER value is the ratio of the difference in cost to the difference in effectiveness between the two strategies.

6. Matching real costs with INA-CBG tariffs

The results of direct medical cost analysis obtained compared to INACBG's rates using SPSS software with Kruskal-Wallis test. 


\section{RESULTS}

Table 1. Direct Medical Cost Components of Type 2 Diabetes Mellitus Patients JKN Participants with Anti-diabetic Combination Inpatient Therapy at Yogyakarta City Hospital in 2017 and 2018

\begin{tabular}{|c|c|c|c|c|c|c|c|c|}
\hline \multicolumn{9}{|c|}{ Mean \pm SD (\%) } \\
\hline Class I & & & & & & & & \\
\hline $\begin{array}{l}\text { Therapy } \\
\text { Pattern }\end{array}$ & $\begin{array}{c}\text { Total } \\
\text { of } \\
\text { patient }\end{array}$ & $\begin{array}{l}\text { Anti- } \\
\text { diabetic } \\
\text { drugs } \\
\text { (Rp) }\end{array}$ & $\begin{array}{c}\text { Non- Anti- } \\
\text { diabetic } \\
\text { drugs } \\
\text { (Rp) }\end{array}$ & $\begin{array}{c}\text { Accommodation } \\
\text { Fee } \\
\text { (Rp) }\end{array}$ & $\begin{array}{c}\text { Service } \\
\text { Fee } \\
\text { (Rp) }\end{array}$ & $\begin{array}{c}\text { Laboratory } \\
\text { Costs \& } \\
\text { Other } \\
\text { Supporting } \\
\text { Costs } \\
\text { (Rp) }\end{array}$ & $\begin{array}{c}\text { Cost of } \\
\text { medical } \\
\text { devices } \\
\text { (Rp) }\end{array}$ & $\begin{array}{c}\text { Direct } \\
\text { Medical } \\
\text { Costs } \\
\text { (Rp) }\end{array}$ \\
\hline $\begin{array}{l}\text { Fast Action } \\
\text { Insulin - } \alpha- \\
\text { Glucosidase }\end{array}$ & 1 & $\begin{array}{c}234,416,2 \pm \\
0(3.87 \%)\end{array}$ & $\begin{array}{c}1,182,701 \pm 0 \\
(19.52 \%)\end{array}$ & $\begin{array}{c}803,000 \pm 0 \\
(13.25 \%)\end{array}$ & $\begin{array}{c}2,209,700 \\
\pm 0 \\
(36.47 \%)\end{array}$ & $\begin{array}{c}439,000 \pm 0 \\
(7.25 \%)\end{array}$ & $\begin{array}{l}1,386,951 \pm \\
o(22.89 \%)\end{array}$ & $\begin{array}{c}6,058,855 \pm 0 \\
(14.31 \%)\end{array}$ \\
\hline $\begin{array}{l}\text { Fast Action } \\
\text { Insulin - } \\
\text { Biguanid } \\
\end{array}$ & 1 & $\begin{array}{l}218.395,867 \\
\pm 0(11.37 \%)\end{array}$ & $\begin{array}{c}517.049 \pm 0 \\
(26.90 \%)\end{array}$ & $\begin{array}{c}318,000 \pm 0 \\
(16.55 \%)\end{array}$ & $\begin{array}{l}352,000 \pm \\
0(18.32 \%)\end{array}$ & $\begin{array}{c}426,500 \pm 0 \\
(22.20 \%)\end{array}$ & $\begin{array}{c}89,638 \pm 0 \\
(4.67 \%)\end{array}$ & $\begin{array}{c}1,921,583 \pm 0 \\
(4.54 \%)\end{array}$ \\
\hline $\begin{array}{l}\text { Fast } \\
\text { Working } \\
\text { Insulin - } \\
\text { Long } \\
\text { Working } \\
\text { Insulin } \\
\end{array}$ & 4 & $\begin{array}{c}281,730 \pm \\
98,171 \\
(6.76 \%)\end{array}$ & $\begin{array}{c}837,834 \pm \\
435,091 \\
(20.11 \%)\end{array}$ & $\begin{array}{c}400,000 \pm \\
154,486(9.60 \%)\end{array}$ & $\begin{array}{c}1,426,700 \\
\pm 1,263,816 \\
(34.25 \%)\end{array}$ & $\begin{array}{c}876,875 \pm \\
867,936 \\
(21.05 \%)\end{array}$ & $\begin{array}{c}391,388 \pm \\
231,791 \\
(9.39 \%)\end{array}$ & $\begin{array}{c}4,166,042 \pm \\
2,334,490 \\
(9.84 \%)\end{array}$ \\
\hline $\begin{array}{l}\text { Fast } \\
\text { Working } \\
\text { Insulin - } \\
\text { Long } \\
\text { Working } \\
\text { Insulin - } \alpha- \\
\text { Glucosidase }\end{array}$ & 1 & $\begin{array}{c}245,246,1 \pm \\
0(3.71 \%)\end{array}$ & $\begin{array}{c}1,109,824 \pm 0 \\
(16.78 \%)\end{array}$ & $\begin{array}{c}928,000 \pm 0 \\
(14.03 \%)\end{array}$ & $\begin{array}{c}1,909,400 \pm \\
0(28.87 \%)\end{array}$ & $\begin{array}{c}991,500 \pm 0 \\
(14.99 \%)\end{array}$ & $\begin{array}{c}1,643,684 \pm \\
0(24.86 \%)\end{array}$ & $\begin{array}{c}6,612,740 \pm 0 \\
(15.61 \%)\end{array}$ \\
\hline
\end{tabular}

The $6^{\text {th }}$ International Conference on Public Health Best Western Premier Hotel, Solo, Indonesia, October 23-24, 2019 | 239 https://doi.org/10.26911/the6thicph-FP.04.03 


\begin{tabular}{|c|c|c|c|c|c|c|c|c|}
\hline $\begin{array}{l}\text { Fast Action } \\
\text { Insulin - } \\
\text { Biguanid - } \\
\text { Sulfonylurea }\end{array}$ & 1 & $\begin{array}{c}8,995,233 \pm \\
0(0.28 \%)\end{array}$ & $\begin{array}{c}854,194 \pm 0 \\
(27.01 \%)\end{array}$ & $\begin{array}{l}531,000 \pm 0 \\
(16.79 \%)\end{array}$ & $\begin{array}{l}782,000 \pm \\
0(24.73 \%)\end{array}$ & $\begin{array}{c}279,500 \pm 0 \\
(8.84 \%)\end{array}$ & $\begin{array}{l}809,227 \pm \\
\text { o }(25.59 \%)\end{array}$ & $\begin{array}{c}3,162,146 \pm 0 \\
(7.47 \%)\end{array}$ \\
\hline \multicolumn{9}{|l|}{ Class II } \\
\hline $\begin{array}{l}\text { Therapy } \\
\text { Pattern }\end{array}$ & $\begin{array}{c}\text { Total } \\
\text { of } \\
\text { patient }\end{array}$ & $\begin{array}{l}\text { Anti- } \\
\text { diabetic } \\
\text { drugs } \\
\text { (Rp) }\end{array}$ & $\begin{array}{l}\text { Non- Anti- } \\
\text { diabetic } \\
\text { drugs } \\
\text { (Rp) }\end{array}$ & $\begin{array}{c}\text { Accommodation } \\
\text { Fee } \\
\text { (Rp) }\end{array}$ & $\begin{array}{c}\text { Service } \\
\text { Fee } \\
\text { (Rp) }\end{array}$ & $\begin{array}{c}\text { Laboratory } \\
\text { Costs \& } \\
\text { Other } \\
\text { Supporting } \\
\text { Costs } \\
\text { (Rp) }\end{array}$ & $\begin{array}{l}\text { Cost of } \\
\text { medical } \\
\text { devices } \\
\text { (Rp) }\end{array}$ & $\begin{array}{c}\text { Direct } \\
\text { Medical } \\
\text { Costs } \\
\text { (Rp) }\end{array}$ \\
\hline $\begin{array}{l}\text { Fast Action } \\
\text { Insulin - } \\
\text { Biguanid }\end{array}$ & 1 & $\begin{array}{c}193,492 \pm 0 \\
(9.46 \%)\end{array}$ & $\begin{array}{c}297,992 \pm 0 \\
(14.57 \%)\end{array}$ & $\begin{array}{c}388,000 \pm 0 \\
(18.97 \%)\end{array}$ & $\begin{array}{l}726,000 \pm \\
0(35.50 \%)\end{array}$ & $\begin{array}{c}307,500 \pm 0 \\
(15.04 \%)\end{array}$ & $\begin{array}{c}131,975 \pm 0 \\
(6.45 \%)\end{array}$ & $\begin{array}{c}2,044,959 \pm 0 \\
(4.83 \%)\end{array}$ \\
\hline $\begin{array}{l}\text { Fast } \\
\text { Working } \\
\text { Insulin - } \\
\text { Long } \\
\text { Working } \\
\text { Insulin }\end{array}$ & 5 & $\begin{array}{c}254,119 \pm \\
92,507,43 \\
(12.95 \%)\end{array}$ & $\begin{array}{c}623,611 \pm \\
297,340,84 \\
(31.78 \%)\end{array}$ & $\begin{array}{c}254,000 \pm 167,869 \\
(12.94 \%)\end{array}$ & $\begin{array}{c}486,300 \pm \\
150,745,48 \\
(24.78 \%)\end{array}$ & $\begin{array}{c}235,400 \pm \\
114,610,97 \\
(12.00 \%)\end{array}$ & $\begin{array}{c}160,198 \pm \\
124,548,03 \\
(8.16 \%)\end{array}$ & $\begin{array}{c}1,962,484 \pm \\
548,216,88 \\
(4.63 \%)\end{array}$ \\
\hline $\begin{array}{l}\text { Long } \\
\text { Working } \\
\text { Insulin - } \\
\text { Long } \\
\text { Working } \\
\text { Insulin - } \\
\text { Fast } \\
\text { Working } \\
\text { Insulin }\end{array}$ & 1 & $\begin{array}{l}438,904,25 \\
\pm 0(8.61 \%)\end{array}$ & $\begin{array}{c}2,230,682 \pm 0 \\
(43.75 \%)\end{array}$ & $\begin{array}{l}320,000 \pm 0 \\
(6.28 \%)\end{array}$ & $\begin{array}{c}1,245,700 \pm \\
0(24.43 \%)\end{array}$ & $\begin{array}{c}200,000 \pm 0 \\
(3.92 \%)\end{array}$ & $\begin{array}{c}828,771 \pm 0 \\
(16.26 \%)\end{array}$ & $\begin{array}{c}5,098,361 \pm 0 \\
(12.04 \%)\end{array}$ \\
\hline
\end{tabular}

The $6^{\text {th }}$ International Conference on Public Health Best Western Premier Hotel, Solo, Indonesia, October 23-24, 2019 | 240 


\begin{tabular}{|c|c|c|c|c|c|c|c|c|}
\hline $\begin{array}{l}\text { Mixed } \\
\text { Analog } \\
\text { Insulin - } \\
\text { Fast Acting } \\
\text { Insulin - } \alpha- \\
\text { Glucosidase }\end{array}$ & 1 & $\begin{array}{c}247.655 \pm 0 \\
(3.91 \%)\end{array}$ & $\begin{array}{c}1.994 .060 \pm 0 \\
(31.51 \%)\end{array}$ & $\begin{array}{c}531.000 \pm 0 \\
(8.39 \%)\end{array}$ & $\begin{array}{c}1.270 .400 \pm \\
0(20.08 \%)\end{array}$ & $\begin{array}{c}1.490 .500 \pm 0 \\
(23.55 \%)\end{array}$ & $\begin{array}{c}1.000 .094 \\
\pm 0 \\
(15.80 \%)\end{array}$ & $\begin{array}{c}6.328 .047 \pm 0 \\
(14.94 \%)\end{array}$ \\
\hline \multicolumn{9}{|l|}{ Class III } \\
\hline $\begin{array}{l}\text { Therapy } \\
\text { Pattern }\end{array}$ & $\begin{array}{c}\text { Total } \\
\text { of } \\
\text { patient }\end{array}$ & $\begin{array}{l}\text { Anti- } \\
\text { diabetic } \\
\text { drugs } \\
\text { (Rp) }\end{array}$ & $\begin{array}{l}\text { Non- Anti- } \\
\text { diabetic } \\
\text { drugs } \\
\text { (Rp) }\end{array}$ & $\begin{array}{c}\text { Accommodation } \\
\text { Fee } \\
\text { (Rp) }\end{array}$ & $\begin{array}{c}\text { Service } \\
\text { Fee } \\
\text { (Rp) }\end{array}$ & $\begin{array}{c}\text { Laboratory } \\
\text { Costs \& } \\
\text { Other } \\
\text { Supporting } \\
\text { Costs } \\
\text { (Rp) }\end{array}$ & $\begin{array}{l}\text { Cost of } \\
\text { medical } \\
\text { devices } \\
\text { (Rp) }\end{array}$ & $\begin{array}{l}\text { Direct } \\
\text { Medical } \\
\text { Costs } \\
\text { (Rp) }\end{array}$ \\
\hline $\begin{array}{l}\text { Fast } \\
\text { Working } \\
\text { Insulin - } \\
\text { Long } \\
\text { Working } \\
\text { Insulin } \\
\end{array}$ & 1 & $\begin{array}{c}310,803 \pm 0 \\
(16.76 \%)\end{array}$ & $\begin{array}{c}744,473 \pm 0 \\
(40.16 \%)\end{array}$ & $43,000 \pm 0(2.32 \%)$ & $\begin{array}{l}490,000 \pm \\
0(26.43 \%)\end{array}$ & $\begin{array}{c}167,500 \pm 0 \\
(9.03 \%)\end{array}$ & $\begin{array}{c}158,388 \pm 0 \\
(8.54 \%)\end{array}$ & $\begin{array}{c}1,853,912 \pm 0 \\
(4.38 \%)\end{array}$ \\
\hline \multicolumn{8}{|c|}{ Average Direct Medical Costs } & $\begin{array}{c}3,539,118 \pm \\
2,019,985,44\end{array}$ \\
\hline
\end{tabular}

The $6^{\text {th }}$ International Conference on Public Health Best Western Premier Hotel, Solo, Indonesia, October 23-24, $2019 \mid 241$ https://doi.org/10.26911/the6thicph-FP.04.03 
Table 2. Discounting Rates of Real Costs for Type 2 Diabetes Mellitus Patients JKN Participants with Anti-diabetic Combination Inpatient Therapy at Yogyakarta City Hospital in 2017 and 2018

\begin{tabular}{cccc}
\hline Year & Number of Patient & Score before Discounting & Score of Discounting \\
\hline 2017 & 12 & $44,564,082$ & $43,161,186$ \\
2018 & 7 & $22,679,314$ & $22,679,314$ \\
\hline
\end{tabular}

Table 3. Calculation Result Results of ACER Type 2 Diabetes Mellitus Patients JKN Participants with Anti-diabetic Combination Inpatient Therapy at Yogyakarta City Hospital in 2017 and 2018

\section{Class I}

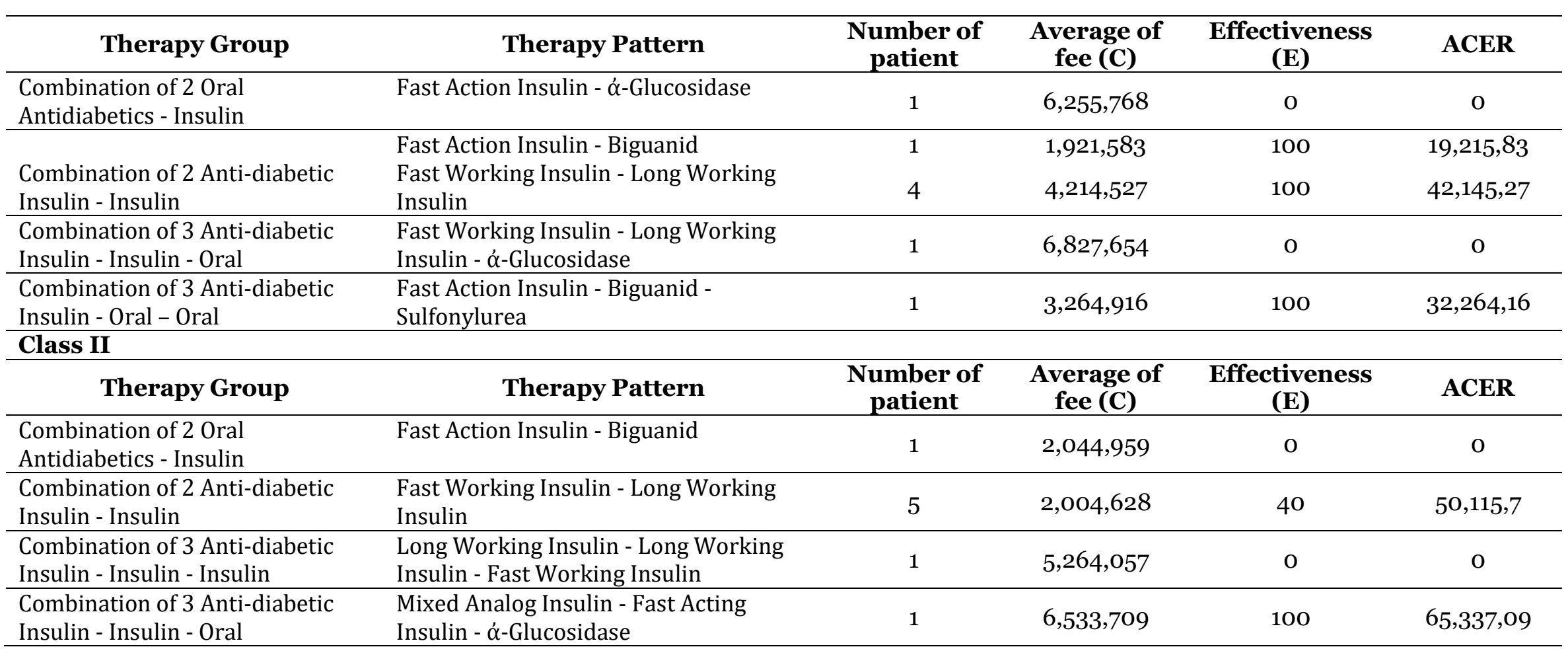

The $6^{\text {th }}$ International Conference on Public Health Best Western Premier Hotel, Solo, Indonesia, October 23-24, 2019 | 242 https://doi.org/10.26911/the6thicph-FP.04.03 


\begin{tabular}{|c|c|c|c|c|c|}
\hline \multicolumn{6}{|l|}{ Class III } \\
\hline Therapy Group & Therapy Pattern & $\begin{array}{l}\text { Number of } \\
\text { patient }\end{array}$ & $\begin{array}{l}\text { Average of } \\
\text { fee (C) }\end{array}$ & $\begin{array}{l}\text { Effectiveness } \\
\text { (E) }\end{array}$ & ACER \\
\hline $\begin{array}{l}\text { Combination of } 2 \text { Anti-diabetic } \\
\text { Oral - Oral }\end{array}$ & Biguanid - Sulfonylurea & 2 & $3,167,592$ & 50 & $63,351,84$ \\
\hline $\begin{array}{l}\text { Combination of } 2 \text { Anti-diabetic } \\
\text { Insulin - Insulin }\end{array}$ & $\begin{array}{l}\text { Fast Working Insulin - Long Working } \\
\text { Insulin }\end{array}$ & 1 & $1,914,164$ & o & o \\
\hline & Total & 19 & & & \\
\hline
\end{tabular}

Table 4. ICER Calculation Result Tables for Type 2 Diabetes Mellitus Patients JKN Participants with Anti-diabetic Combination Therapy Inpatients at Yogyakarta City Hospital in 2017 and 2018

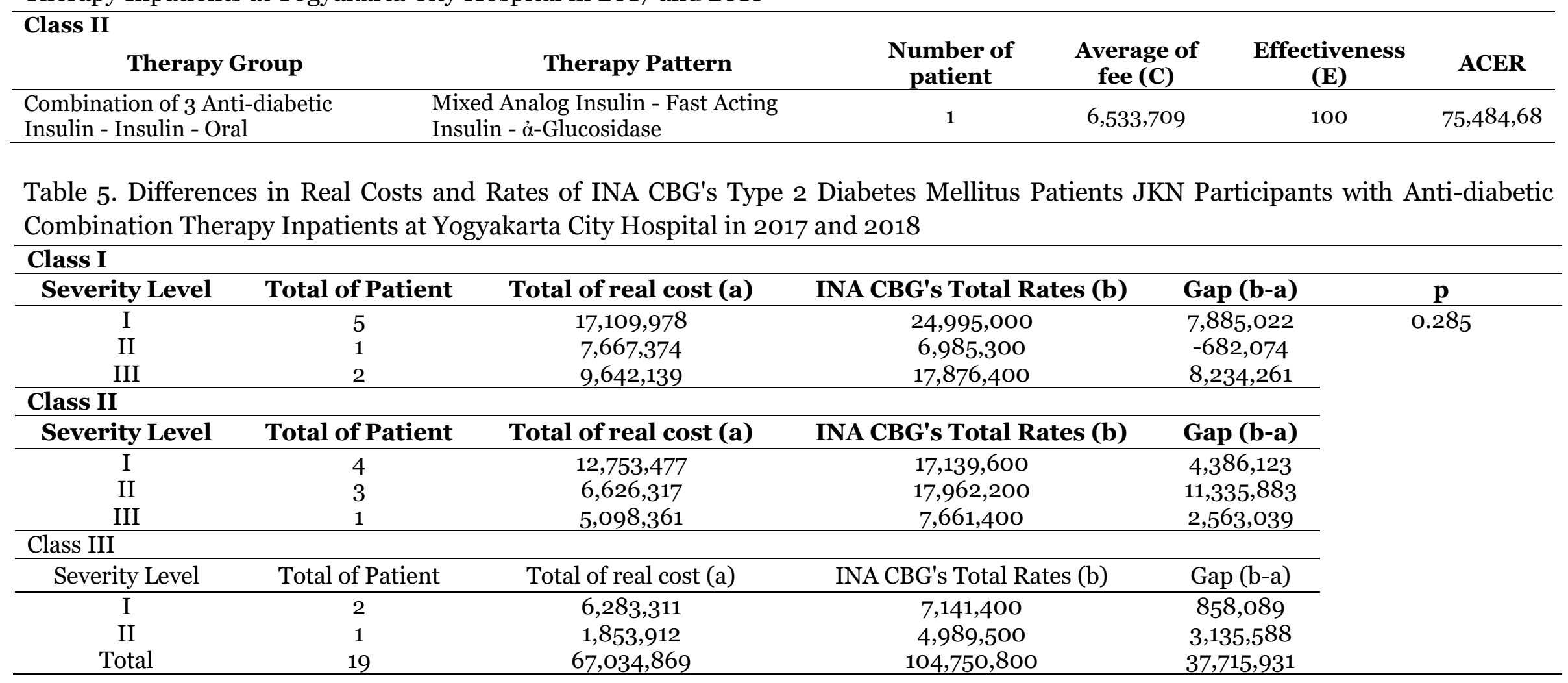




\section{DISCUSSION}

The most cost-effective ACER value in class I is combination therapy with fast acting insulin and biguanid with ACER value of 19,215.83 . This study is in accordance with Ni Komang EW's research (2012) which states that the most cost-effective therapy is aspart insulin combination therapy which is fast acting insulin with metformin which is included in the biguanid group has the smallest ACER value of Rp 7,946.00/\% effectiveness of therapy (Wahyuni et al., 2012).

The most cost-effective therapy in class II is a combination of fast acting insulin and long acting insulin with a ACER value of $\mathrm{Rp}$ $50,115.7$, the results of this study are in accordance with Kartika et al. (2013) which states that combination therapy of insulin glargine which is a group of long acting insulin with insulin aspart which is a group of fast acting insulin has high effectiveness because insulin aspart can provide rapid onset of action and insulin glargine has a longer duration of action so that it can mimic the normal insulin profile the body, besides that the price is cheaper so it is more widely used as an alternative therapy by patients with type 2 diabetes mellitus (Kartika et al., 2013).

In class III, the most cost-effective therapy is combination therapy of biguanid and sulfonylureas with ACER value of Rp 63,351.84 which is in accordance with Achmad Harjanto's research (2016) which states that the most cost-effective therapy is combination therapy of biguanid and glimepiride class groups sulfonylureas with ACER values of $\mathrm{Rp}$ 11,203.54 (Harjanto and Achmad, 2016). ICER calculation is done if there is an intervention that has a lower cost and effectiveness lower than the standard intervention (ACER) as well as an intervention that has a higher cost and higher effectiveness than a standard interven- tion (ACER). ICER calculation is intended to be able to provide alternative choices to patients. These alternative choices can be adjusted with consideration of funds owned by patients (Ministry of Health, 2013). Table 4 shows that only combination therapy of mixed analog insulin, fast acting insulin, and $\dot{\alpha}$-glucosidase in class II has higher costs and higher effectiveness compared to ACER values, so ICER calculations need to be done.

ICER value of $R p \quad 75,484,68$, namely mixed analog insulin combination therapy, fast acting insulin and II-glucosidase class II with severity I, so that mixed analog insulin combination therapy, fast acting insulin and $\dot{\alpha}^{-}$ glucosidase cannot be used as alternative therapies because of the average the direct medical costs required for Class II patients with severity I to be able to use the combination of these therapies exceeded the INA CBG rates of Class II patients with severity I. Rates of INA CBG's class II diabetes mellitus patients with class I severity level were $\operatorname{Rp~4,284,900.~}$

The $\mathrm{p}$ value obtained from the KruskalWallis method is 0.29 so that $p>0.05$ shows that there is no significant difference between the real costs and INA CBG rates. This might be due to the average type 2 diabetes mellitus patient being hospitalized for only about 6 days in the hospital, so that the real costs do not swell especially the hospital accommodation costs.

The difference between the real costs and the INA CBG rate is Rp 37,715,931, where the INA CBG's tariff is greater than the real cost, so it can be concluded that the hospital has not suffered losses due to the JKN program. Judging from the difference in value between real costs and INA CBG rates, it shows that hospitals get greater benefits because the value of real costs is lower compared to INA CBG rates, so it is expected that hospitals can improve

The $6^{\text {th }}$ International Conference on Public Health Best Western Premier Hotel, Solo, Indonesia, October 23-24, 2019 | 244 https://doi.org/10.26911/the6thicph-FP.04.03 
their quality in all fields and always evaluate so that losses do not occur.

The current study indicates similarity with previous ones (Pramestinityas, 2014) showing no significant difference between the real costs and INA CBG's rates in patients with type 2 DM inpatients at Dr. Soebandi Jember Hospital $(p=0.923)$ which means the effectiveness of achieving insulin is not significantly different from the combination therapy of insulin and metformin (Esty, 2014).

The results from this study is not automatically generalizable to other hospitals because diabetes mellitus has different levels of severity so that the effectiveness of therapy is different according to severity. These differences cause differences in real costs and INA CBG rates.

\section{REFERENCES}

Harjanto A (2017). Analisis Efektifitas Biaya Antidiabetik Oral pada Penderita Diabetes Melitus Tipe 2 Rawat Inap Peserta BPJS di RSUD Sukohardjo, Surakarta (Analysis of the Effectiveness of Oral Anti-diabetic Costs in Type 2 Diabetes Mellitus Patients Inpatient at BPJS Participants in Sukohardjo District Hospital, Surakarta.).

International Diabetes Federation (2015). IDF Diabetes Atlas, $5^{\text {th }}$ Edition.

Janis N (2014). Supply dan Demand Terhadap Layanan Kesehatan.

Kartika IGAA, Lestari AAW, Swastini DA (2013). Perbandingan Profil Penggunaan Terapi Kombinasi Insulin pada Pasien Diabetes Melitus Tipe 2 Di Unit Rawat Inap Rumah Sakit Umum Pusat (RSUP) Sanglah, Bali (Comparison of Profiles of Use of Insulin Combination
Therapy in Type 2 Diabetes Mellitus Patients in the Inpatient Unit of the Central General Hospital (RSUP) Sanglah, Bali).

Ministry of Health (2013). Peraturan Menteri Kesehatan RI Nomor 71 Tahun 2013 tentang Pelayanan Kesehatan pada Jaminan Kesehatan Nasional, Kementerian Kesehatan Republik Indonesia, Jakarta.

Ministry of Health (2013b). Peraturan Menteri Kesehatan Republik Indonesia Nomor 69 tahun 2013, Kementerian Kesehatan Republik Indonesia, Jakarta.

Ministry of Health (2014). Peraturan Menteri Kesehatan RI Nomor 59 Tahun 2014 tentang Standar Tarif Pelayanan Kesehatan dalam Penyelenggaraan Program Jaminan Kesehatan, Kementerian Kesehatan Republik Indonesia, Jakarta.

PERKENI (2015). Konsensus pengelolaan diabetes melitus tipe 2 diIndonesia 2015, PB PERKENI, Semarang.

Sunarto (2011). Sistem Pembiayaan dan Skema Kelembagaan Jaminan Kesehatan Daerah Kota Yogyakarta (Yogyakarta City Regional Health Insurance Institutional Financing System and Scheme). J Kesehatan Masy Nasional masyarakat Nas.

Wahyuni NKE (2012). Analisis Efektivitas Biaya Penggunaan Terapi Kombinasi Insulin dan OHO pada Pasien Diabetes Melitus Tipe 2 Rawat Jalan di RSUD Wangaya, Universitas Udayana, Bali (Cost Effectiveness Analysis of the Use of Combination Therapy of Insulin and OHO in Type 2 Diabetes Mellitus Patients Outpatient at Wangaya Hospital, Udayana University, Bali). 